Dicle Tip Dergisi / Dicle Med J (2018) 45 (1) : 97 - 101

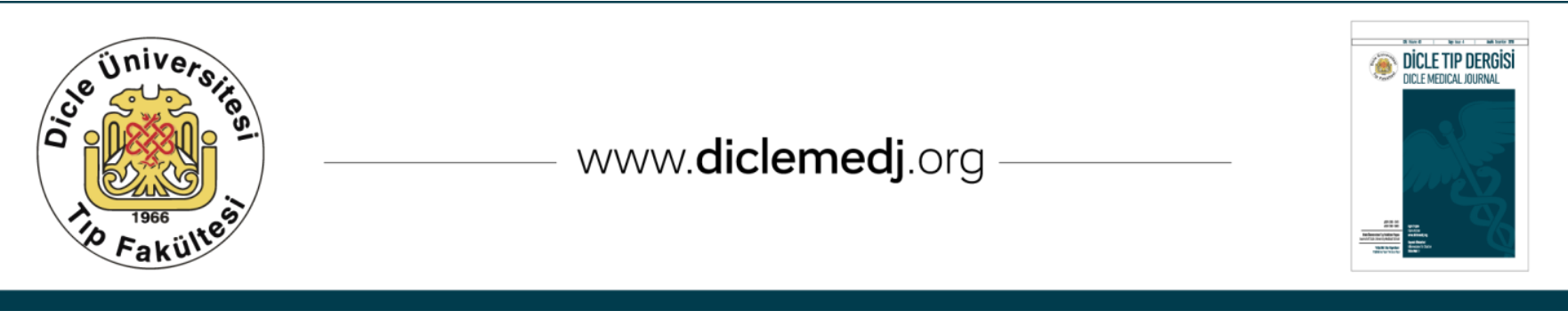

Olgu Sunumu / Case Report

\title{
İmmunkompetan Bir Cerrahta Gelişen Akut Cytomegalovirus Hepatiti
}

\author{
Esra Tanyel ${ }^{1}$, Meltem Çelik Karslığlu ${ }^{2}$, Şaban Esen ${ }^{3}$ \\ 1 Ondokuzmayıs Üniv Tip Fak, Enfeksiyon Hast ve Klinik Mikrobiyoloji Anabilim Dall, Samsun, Türkiye ORCID: 0000-0002-3151-371X \\ 2 Ondokuzmayıs Üniv Tıp Fak, Enf Hast ve Klinik Mikrobiyoloji Anabilim Dalı, Samsun, Türkiye ORCID: 0000-0001-8490-3757 \\ 3 Ondokuzmayıs Üniv Tıp Fak, Enfeksiyon Hast ve Klinik Mikrobiyoloji Anabilim Dalı, Samsun, Türkiye ORCID: 0000-0002-7947-4692
}

Geliş: 28.04.2017, Revizyon: 05.09.2017, Kabul Tarihi: 05.10.2017

\begin{abstract}
Özet
İmmunkompetan kişilerde Cytomegalovirus (CMV) infeksiyonu asemptomatik veya mononükleoz benzeri bir tablo ile seyreder, şiddetli hastalık gelişmesi nadirdir. CMV kan, vücut sıvıları, cinsel, plasental yolla ve transplante edilen organlar aracılığı ile bulaşır. Burada önceden sağlıklı olan genç bir erkekte gelişen ve polimeraz zincir reaksiyonu (PZR) CMV DNA ile tanısı konulan akut CMV hepatiti olgusu sunulmuştur. Yirmi sekiz yaşında erkek cerrah kliniğimize üç haftadır devam eden ateş yakınması ile başvurdu. Kabulünde vücut sıcaklığı 380C ve fizik muayenesi hepatomegali dışında normaldi. Laboratuvarında beyaz küre sayısı hafifçe artmış $(10000 / \mathrm{mm} 3)$ ve periferik kan yaymasında atipik lenfositler $(>10 \%)$ mevcuttu. Karaciğer fonksiyon testleri artmıștı ve geniș serolojik taramada herhangi bir viral hepatit etkeni izole edilemedi. CMV IgM pozitif ve IgG negatif olarak saptandı. Kanda PZR CMV DNA (1150 kopya/mL; normal aralık<150kopya/mL) yüksek saptandı. Gansiklovir tedavisi başlandıktan sonra karaciğer fonksiyon testleri ve genel durumu düzeldi. Literatürde immunkompetan kişilerde gelişen CMV hepatiti olguları rapor edilmiştir. Ayrıca CMV'ye bağlı kolestatik hepatit, granülomatöz hepatit veya karaciğer transplantasyonu gerektiren fulminant karaciğer yetmezliği de bildirilmiştir. CMV infeksiyonu/hastalığı tanısında; virus kültürü, seroloji, CMV antijenemi, histopatoloji ve PZR yöntemleri kullanılabilir. Anti-CMV immunglobulinlerin akut infeksiyon daspesifite ve sensitivitesi düşüktür. Kanda bakılan PZR CMV DNA tanıda altın standarttır ve özellikle kantitatif ölçümü tedavi takibi için önemlidir. Bu olgu sağlıklı kişilerde ateş, hepatomegali ve karaciğer fonksiyon testlerinde yükseklik saptandığında sıklıkla karşılaşılan etiyolojik nedenler dışlandığında CMV'ünde bu tabloya yol açabileceğini düşündürmesi açısından önemlidir.
\end{abstract}

Anahtar kelimeler: Cytomegalovirus, hepatit, immunkompetan konak

DOI: $10.5798 /$ dicletip.407252

Yazışma Adresi / Correspondence: Esra Tanyel, Ondokuzmayıs Üniversitesi Tıp Fakültesi, Enfeksiyon Hastalıkları ve Klinik Mikrobiyoloji Anabilim Dalı, Samsun, Türkiye,55139 e-mail: estanyel@yahoo.com.tr 


\title{
Acute Cytomegalovirus Hepatitis In An Immunocompetent Surgeon
}

\begin{abstract}
Cytomegalovirus (CMV) infection in the immunecompetent individual is asymptomatic or manifested as a mononucleosis-like syndrome, and severe organ damage is rarely reported.

CMV is transmitted through blood, body fluids, sexual and placental transfer, and transplanted organs. Here, we describe a previously healthy male patient of acute CMV hepatitis in whom the diagnosis was established by polymerase chain reaction (PCR) CMV-DNA. A 28-year-old males urgeon was admitted tour out patient clinic with complaints of fever for three weeks. Upon admission the patient presented body temperature was 380C and physical examination revealed normal finding sotherthanhepatomegaly. Laboratory data revealed a slightly increased white blood cell $(10000 / \mathrm{mm} 3)$ with a typically mphocytes $(>10 \%)$ in peripheral blood smear. His liver enzyme concentrations were elevated and an extensive serological screening to identify any viral cause of hepatitis. The CMV IgM was positive, and IgG was negative. PCR of his blood was elevated for CMV DNA (1150 copies/mL; normal range $<150$ copies $/ \mathrm{mL}$ ). Treatment with ganciclovir was initiated, after which his liver function began to improve and her general condition recovered. In the literature, several immune competent cases with CMV hepatitis have been reported. In addition, patients may develop cholestatic hepatitis, granulomatous hepatitis, or fulminant hepatic failure requiring liver transplantation due to CMV infection. Viral culture, serology, CMV antigenemia, histopathological examination, and PCR can be used in the diagnosis of CMV infections. Anti-CMV immunoglobulins have low specificity and sensitivity during acute infection. The gold standard in the diagnosis is CMV-DNA level measured in the blood using PCR, and quantitative measurement is particularly important for follow-up. The present case report is note worthy for reminding $\mathrm{CMV}$ as an etiological factor for clinical presentation with fever, hepatomegaly, and elevated liver enzymes, when other factor sare excluded.
\end{abstract}

Keywords: Cytomegalovirus, hepatitis, immunocompetenthost

\begin{tabular}{llll}
\multicolumn{4}{c}{ GíRiş } \\
Herpes grubundan bir & virus olan \\
Cytomegalovirus (CMV) & infeksiyonları
\end{tabular} immunkompromize kişilerde önemli morbidite ve mortalite nedenidir ${ }^{1,2}$. Bu kişilerde CMV akciğer, göz ve gastrointestinal sistemi etkileyerek ağır hastalık tablolarına yol açabilir. Gelişen tablo primer infeksiyondan çok reaktivasyondur ${ }^{2-4}$. İmmunkompetan kişilerde hastalık sıklıkla asemptomatik seyretmekle birlikte, \%10 hastada ateș, halsizlik, karaciğer fonksiyon testlerinde artış ve atipik lenfozitoz ile karakterize mononükleoz benzeri bir tabloya da yol açabilir1,5. Primer infeksiyondan sonra CMV birçok organda latent olarak kalıp, ağır immun sistem hasarında reaktive olabilir ${ }^{3}$. Seroprevalansı yaşa, toplumun gelişmişlik düzeyini bağlı olmakla birlikte \%45-100 arasında değişmektedir ${ }^{2,5}$.

İmmunkompetan kişilerde ağır hastalık gelişimi nadir olmakla birlikte CMV'ye bağlı sıklıkla gastrointestinal sistem olmak üzere farklı organ tutulumları gelişebilir6-8. Burada sağlıklı ve genç bir kişide gelişen akut CMV hepatiti sunulmuştur.

\section{OLGU SUNUMU}

Yirmi sekiz yaşında erkek hasta, 20 gündür olan ateş, üşüme, titreme, halsizlik, yorgunluk ve bulantı yakınmaları ile polikliniğe başvurdu. Nefrolitiazis dışında bilinen bir hastalığ olmayan hasta sigara, alkol kullanmiyordu, seyahat ve kan transfüzyonu öyküsü de yoktu. Hastanın ilk başvurusunda ateş:380C, kan basincl: 110/70 mmHg, solunum sayısı: 18/dk idi. Fizik muayenesinde hepatomegali dişında patolojik bulgu yoktu.

Laboratuar tetkikleri: Beyaz küre: 10000/mm3 (3700-9700/uL), lenfosit: 6200/mm3 (1100$3300 / \mathrm{uL})$, trombosit sayısi: $189000 / \mathrm{mm} 3$ (179000-373000/uL), C-reaktif protein: $4.5 \mathrm{mg} / \mathrm{dL}(0-0.35 \mathrm{mg} / \mathrm{dL})$, alanin transaminaz (ALT): $\quad 150 \mathrm{U} / \mathrm{L} \quad(0-40 \quad \mathrm{U} / \mathrm{L}), \quad$ aspartat transaminaz (AST): 92U/L (8-46 U/L), total 
bilirubin/direk bilirubin: $0.8 / 0.4 \mathrm{mg} / \mathrm{dL}$, alkalin fosfataz (ALP): 309U/L (40-120 U/L), gamaglutamil transferaz (GGT):206U/L (8-61 U/L) ve laktat dehidrogenaz (LDH): 405U/L (0-480 $\mathrm{U} / \mathrm{L}$ ) idi. Karaciğer fonksiyon testlerinde yükseklik olması üzerine etiyolojiye yönelik yapılan HBsAg, Anti HBcIgM, anti HAV IgM, anti-HCV, anti-HIV ve brusella tüpaglütinasyon testleri testlerine gatif tespit edildi. Kliniğimizde bakılan kan tetkiklerinin günler içindeki seyri Tablo 1'de görülmektedir. Ateşi olan hastadan alınan kan ve idrar kültürlerinde üreme olmadı. Yapılan abdominal ultrasonografide hepatomegali $(204 \mathrm{~mm})$ dışında başka patolojiye rastlanılmadı. Periferik yaymasında atipik lenfositler (>\%10) saptanması üzerine EBV (Epstein-Barr Virus) ve CMV'e yönelik serolojiktestler istendi. EBVVCA IgM (-), EBV-EBNA IgG (+) ve Anti-CMV $\operatorname{IgM}(+)$, IgG (-)(VIDAS $\AA$, Biomerieux) tespit edildi. Başlangıçta Anti-CMV IgG (-) olduğundan avidite çalışılmadı. Takiplerinde 4 hafta sonra Anti-CMV IgG titresinde artış tespit edildi.Ateşi devam eden ve karaciğer fonksiyon testleri artan hastada bakılan PZR CMV DNA: 1150 kopya/mL (<150kopya/mL-COBAS®, TaqMan, Roche) olarak bulundu. PZR yüksek tespit edilen hastadan histopatolojik inceleme için biyopsi yapılmadı. CMV hepatiti tanısıyla yatırlan hastaya IV gansiklovir 2 x $5 \mathrm{mg} / \mathrm{kg}$ tedavisi başlandı. Tedavinin 48 . saatinden sonra hastanın ateși olmadı ve tedavinin birinci haftasinda PZR CMV DNA: $<150$ kopya/mL olarak tespit edildi. Hastanın tedavisi oral valgansiklovir $1 \times 900 \mathrm{mg} / g u ̈ n ~ i l e ~ 14$ güne tamamlandı. Tedavi süresince ilaca bağlı yan etki görülmedi.

\section{TARTIŞMA}

Primer CMV infeksiyonları sıklıkla erken çocukluk veya adölesan dönemde asemptomatik veya kendini sinırlayan hafif seyirli bir enfeksiyon olarak geçirilmektedir. Bulaş tükrük, idrar, genital sekresyonlar, anne sütü veya kan aracılığı ile gelişir1,5,8. Primer infeksiyondan sonra CMV konakta başlıca lökositlerin içinde latent olarak kalırken, immun sistemin baskılandığ durumlarda reaktive olabilir. Özellikle akciğer, gastrointestinal sistem ve plasental dokuda bulunan fibroblastlar, epitelyal hücreler, düz kas hücreleri, makrofajlar ve endotelyal hücreler CMV'nin replike olduğu hücrelerdir. İmmunkompromize kişilerde (kazanılmış immun yetmezlik sendromu-AIDS, transplantasyon veya iritabl barsak hastalığı) hem primer enfeksiyon hem de reaktivasyon pnömoni, gastrointestinal hastalık, retinit gibi ağır klinik tablolarla seyreder. Ancak immunkompetan kişilerde ağır hastalık gelişimi nadirdir ${ }^{4,5}$.

Tablo 1: Hastanın takip süresince hematolojik ve biyokimyasal değerleri

\begin{tabular}{llllll}
\hline & 1.gün & 4.gün & 8.gün & 12.gün & Normal aralık \\
\hline Beyaz küre & 12700 & 10600 & 7900 & 7200 & $3700-9700 / \mathrm{uL}$ \\
Lenfosit sayısı & 6200 & 6200 & 4800 & 3600 & $1100-3300 / \mathrm{LL}$ \\
AST & 96 & 65 & 46 & 35 & $8-46 \mathrm{U} / \mathrm{L}$ \\
ALT & 178 & 139 & 93 & 72 & $0-40 \mathrm{U} / \mathrm{L}$ \\
LDH & 405 & & & & $0-480 \mathrm{U} / \mathrm{L}$ \\
GGT & 206 & 142 & 102 & 87 & $8-61 \mathrm{U} / \mathrm{L}$ \\
ALP & 309 & & & 153 & $40-120 \mathrm{U} / \mathrm{L}$ \\
Bilirubin & $0.8 / 0.4$ & $0.6 / 0.2$ & & $0.5 / 0.2$ & $0.1-1.5 / 0-0.4 \mathrm{mg} / \mathrm{dL}$ \\
Kreatin & 1.01 & 0.9 & 1 & 1.02 & $0.4-1.4 \mathrm{mg} / \mathrm{dL}$ \\
\hline
\end{tabular}


İmmunkompetan kişilerde primer CMV infeksiyonu sirasinda olguların \%90'ında karaciğer fonksiyon testlerinde hafif veya orta dereceli artış görülür. ALT artışı, AST artışından daha belirgin olup, GGT, ALP ve bilirubin seviyelerinde artış nadirdir. Genellikle bu tablo hafif şiddette olup kendini sınırlar ve haftalar içinde normale döner 1,2. Bununla birlikte nadiren şiddetli kolestatik hepatit, granülomatoz hepatit veya akut karaciğer yetmezliği de gelișebilir 7,9 . Olgumuzdaha önceden bilinen bir hastalığı olmayangenç erkek olup ateş, hepatomegali, karaciğer fonksiyon testleri yüksekliği ve PZR CMV DNA:1150 kopya/mL olması üzerine akut CMV hepatiti tanısı almıştır.

CMV enfekte kişilerin idrar, ter ve tükürükleri aracılı̆̆ $ı$ ile de bulaşabildiğinden, özellikle sağlık çalışanlarında mesleki olarak bulaş riski daha yüksektir. Özellikle prenatal veya postnatal dönemde enfekte olan çocuklar aylarca idrar ve tükürükleri ile virüsü saçtıklarından CMV bulaşı açısından gözden kaçan risk grubu olabilir ${ }^{10}$.Burada sunulan olgu da bir cerrah olduğundan mesleki olarak enfekte hastaların vücut sıvılarına maruz kalmış olabilir.

CMV infeksiyonu/hastalığ kültürü, seroloji, CMV antijenemi, histopatoloji ve PZR yöntemleri kullanılabilir ${ }^{2,3}$.CMV IgM primer infeksiyondan sonra 2-6 hafta içinde yükselir ve 2-3 ay içinde düşmeye başlar. Ancak CMV spesifik antikorlar reaktivasyonda veya akut infeksiyonda tek başına tanı koymak için yeterli değildir. CMV antijenemi metodu \%60100 sensitif, \%83-100 spesifik olmakla birlikte lökopenik hastalarda antijenemi testinin sensitivitesi düşüktür. Kalitatif veya kantitatif PZR CMV DNA kan, idrar, dışkı ve doku örneklerinde gösterilebilir ${ }^{3,11}$. Olgumuzda başlangıçta istenen Anti-CMV IgM (+) olması, viral hepatite yönelik laboratuvar tetkiklerinin negatif çıması ve ateşinin devam etmesi üzerine PZR CMV DNA istenmiş ve yüksek tespit edilmiştir. CMV infeksiyonu/hastalığının immunkompromize hastalarda tedavisi kılavuzlarda tanımlanmıştır. Tedavide ilk seçenek olarak Gansiklovir veya valgansiklovir önerilmektedir. İmmunkompetan bireylerde şiddetli hastalıkla antiviral tedavi kullanımı konusunda kesin fikir birliği olmamakla birlikte tedavi hasta bazında değerlendirilmelidir. Çünkü kullanılacak antivirallerin kemik iliği supresyonu, teratojenite ve santral sinir sistemi hastalığ gibi yan etkileri mevcuttur ${ }^{2,3,5}$.Bununla birlikte farklı vaka raporlarında immunkompetan bireylerde antiviral tedavi kullanıldığı, özellikle ağır CMV infeksiyonunda erken dönemde verilen antiviral tedavinin akut dönemdeki infeksiyonun şiddetini azalttığ belirtilmiştiri,7,12,13. Olgumuzda immunkompetan olmakla birlikte ateşinin devam etmesi, karaciğer fonksiyon testlerinin zamanla artış göstermesi üzerine IV gansiklovir tedavisi başlanmasına karar verilmiştir. Tedavi başlanması için temel alınacak eşik değer çalışılan merkeze göre değişmekle birlikte, tedavi sonlandırılmasında viral klirensin dökümante edilmesi önerilmektedir8.

Tedavi süresince ilaca bağlı yan etki görülmedi ve tedavinin birinci haftasinda PCR CMV DNA: $<150$ olması üzerine oral valgansiklovir ile toplam tedavisi 14 güne tamamlandı.

Sonuç olarak bu olgu sağlıklı kişilerde de CMV'ün hepatite yol açabildiğini ve klinik tablo kendiliğinden gerilemediğinde antivirallerle başarılı bir şekilde tedavi edilebildiğini göstermesi açısından önemlidir.

*Bu olgu KLIMIK Sempozyumu 2017'de (Antalya-Türkiye) poster olarak sunulmuştur.

Çıkar Çatışması Beyanı: Yazarlar çıkar çatışması olmadığını bildirmişlerdir.

Finansal Destek: Bu çalışma her hangi bir fon tarafından desteklenmemiştir. 
Declaration of Conflicting Interests: The authors declare that they have no conflict of interest.

Financial Disclosure: No financial support was received.

\section{KAYNAKLAR}

1. Yu YD, Park GC, Park PY, et al. Cytomegalovirus infection-associated fulminant hepatitis in an immunocompetent adult requiring emergency livingdonor liver transplantation: report of a case. Surg Today. 2013;43:424-8.

2. Jain M, Duggal S, Chugh TD. Cytomegalovirus infection in non-immuno suppressed critically ill patients. J Infect Dev Ctries. 2011;5:571-9.

3. Nakase H, Herfarth H. Cytomegalovirus Colitis, Cytomegalovirus Hepatitis and Systemic Cytomegalovirus Infection: Common Features and Differences. Inflamm Intest Dis. 2016;1:15-23

4. Canterino JE, McCormack M, Gurung A, Passarelli J, Landry ML, Golden M. Cytomegalovirus appendicitis in an immunocompetent host. J ClinVirol. 2016;78:9-11.

5. Lancini D, Faddy HM, Flower R, Hogan C. Cytomegalovirus disease in immunocompetent adults. MJA. 2014; 201:578-580.

6. Jen-WeiChou, Ken-ShengCheng. Pulmonaryembolism in an immunocompetent patient with acute Cytomegalovirus colitis. Intest Res. 2016;14:187-190.
7. Ruiz MF, Codoceo CM, Medrano FL, et al. Cytomegalovirus Myopericarditis and Hepatitis in an Immunocompetent Adult: Successful Treatment with Oral Valganciclovir. Inter Med. 2008; 47: 1963-1966.

8. Jensen KO, Angst E, Hetzer FH, Gingert C. Acute cytomegalovirus hepatitis in an immuncompetent host as a reason for upper right abdominal pain. Case Rep Gastroenterol. 2016; 10: 36-43.

9. Gupta P, Suryadevara M, Das A. Cytomegalovirusinducedhepatitis in an immuncompetent patient. Am J Case Rep. 2014; (15): 447-449.

10. Stranzinger J, Kindel J, Henning M, Wendeler D, Nienhaus A. Prevalence of CMV infection among staff in a metropolitan children's hospital-occupational health screening findings. GMS Hyg Infect Control. 2016; 27:17.

11. Al-Omari A, Aljamaan F, Alhazzani W, Salih S, Arabi Y. Cytomegalovirus infection in immuncompetent critically ill adults: literatüre review. Intensive Care. 2016; 6; (110):1-14.

12. Müller NF, Schampera M, Jahn G, Malek NP, Berg CP, Hamprecht K. Case report: severe Cytomegalovirus primary infection in an immunocompetent adult with disseminated in travascular coagulation treated with valganciclovir. BMC Infect Dis. 2016;16:1-6.

13. Magno Palmeira M, Umemura Ribeiro HY, Garcia Lira $\mathrm{Y}$, et al. Heart failure due to Cytomegalovirus myocarditis in immunocompetent young adults: a case report. BMC Res Notes. 2016;5:391:1-5. 